\title{
The Neuroprotective Effect of Nasturtium officinale on Learning Ability and Density of Parvalbumin Neurons in the Hippocampus of Neurodegenerative-Induced Mice Model
}

(Kesan Neuropelindung Nasturtium officinale pada Keupayaan Pembelajaran dan Kepadatan Neuron Parvalbumin di Hipokampus Model Tikus Teraruh Neurodegeneratif)

\author{
WARIT RUANGLERTBOON, EKKASIT KUMARNSIT, SUKANYA DEJ-ADISAI, \\ URAPORN VONGVATCHARANON \& WANDEE UDOMUKSORN*
}

\begin{abstract}
According to European traditional pharmacopeia, as well as in Chinese traditional medicine, watercress (Nasturtium officinale) has a property in enhancing physical stamina during stress condition. The aim of the study was to evaluate the neuroprotective effects of watercress extract (WCE) on dexamethasone-induced neurodegeneration in mice. Swiss albino male mice $(35-40 \mathrm{~g})$ were divided into 6 groups: double distilled water (DW) and normal saline solution (NSS) (DW+NSS), $D W$ and dexamethasone (DW+DEX)-treated for 21 days, $80 \mathrm{mg} / \mathrm{kg}$ of watercress extract (WCE) and NSS (80WCE $+N S S)$, and WCE-treated (14 days prior to and during dexamethasone treatment) at variable doses of $20 \mathrm{mg} / \mathrm{kg}(20 \mathrm{WCE}+D E X), 40$ $\mathrm{mg} / \mathrm{kg}(40 \mathrm{WCE}+\mathrm{DEX})$, and $80 \mathrm{mg} / \mathrm{kg}(80 \mathrm{WCE}+\mathrm{DEX})$. At the end of the experiment, animals were tested for spatial memory and learning ability by Morris Water Maze apparatus to determine the escape latency time (ELT), and the density of parvalbumin $(P V)$-immunoreactive ( $P V$-ir) neurons in the hippocampus of the brain, using immunohistochemistry. After dexamethasone treatment, the animals had significantly lower body weight, higher ELT and reduced density of PV-ir neurons in the CA1 and CA2 regions of the hippocampus, compared to the control animals. These parameters partially improved in animals supplemented with WCE but without a dose-related pattern. This study suggests that WCE may be beneficial for neuroprotection in stress-induced neurodegeneration.
\end{abstract}

Keywords: Hippocampus; Nasturtium officinale; neurodegeneration; parvalbumin neurons; spatial memory

\section{ABSTRAK}

Menurut farmakopeia tradisi Eropah dan perubatan tradisi China, selada air (Nasturtium officinale) mempunyai sifat dalam meningkatkan stamina fizikal semasa keadaan stres. Tujuan kajian ini adalah untuk menilai kesan neuropelindung daripada ekstrak selada air (WCE) pada deksametason-teraruh neurodegenerasi pada tikus. Tikus jantan Swiss Albino (35-40 g) telah dibahagikan kepada 6 kumpulan: Air suling dua kali (DW) dan larutan garam biasa (NSS) (DW +NSS), DW dan deksametason (DW + DEX)-dirawat selama 21 hari, $80 \mathrm{mg} / \mathrm{kg}$ daripada ekstrak selada air (WCE) dan NSS (80WCE + NSS), dan WCE-dirawat (14 hari sebelum dan semasa rawatan deksametason) pada pelbagai dos $20 \mathrm{mg} / \mathrm{kg}(20 \mathrm{WCE}+$ DEX), $40 \mathrm{mg} / \mathrm{kg}(40 \mathrm{WCE}+\mathrm{DEX})$, dan $80 \mathrm{mg} / \mathrm{kg}(80 \mathrm{WCE}+$ DEX). Pada akhir uji kaji, haiwan telah diuji untuk ingatan ruang dan keupayaan belajar menggunakan perkakasan Lorongan Keliru Morris untuk menentukan waktu lepas kependaman (ELT), dan ketumpatan neuron parvalbumin (PV)-imunoreaktif (PV-ir) pada hipokampus otak menggunakan imunohistokimia. Selepas rawatan deksametason, tikus mempunyai berat badan yang jauh lebih rendah, ELT lebih tinggi dan kurang ketumpatan neuron PV-ir di kawasan CAl dan CA2 hipokampus berbanding dengan tikus kawalan. Parameter ini sebahagiannya bertambah baik pada haiwan yang diberikan WCE tetapi tanpa corak yang berkaitan dengan dos. Kajian ini menunjukkan bahawa WCE mungkin bermanfaat untuk neuropelindung dalam neurodegeneratif teraruh tekanan.

Kata kunci: Hipokampus; ingatan ruang; Nasturtium officinale; neurodegeneratif; parvalbumin neuron

\section{INTRODUCTION}

Dementia is a syndrome indicated by the deterioration of cognitive function ( $\mathrm{Ng} 2016)$. The patients' clinical presentation includes various types of erroneous cognitive behaviors such as the cognitive deficit, the inability of doing household tasks or malfunction of learning ability. Elderly people are at the highest risk of developing dementia due to their advanced age, which may cause malfunction or death of neurons in the hippocampus; this brain area is vital for cognition, learning, and memory (Ballard et al. 2011). In Alzheimer's disease, in which all the mentioned defects are its hallmarks, the hippocampus is almost always damaged (Ball 1978; Coleman \& Flood 1987). This brain area is very sensitive to hypoxia and oxidative stress (Behl 1998). The hippocampus possesses specific receptors for glucocorticoids, and long-term exposure to the hormones led to dendritic atrophy and neuronal apoptosis in the region (Chrousos \& Kino 2009; Woolley et al. 1990; 
Yun et al. 2003). The glucocorticoid-receptor binding induces alteration in $\mathrm{Ca}^{++}$homeostasis, increases reactive oxygen species and alters outer membrane permeability of mitochondria (Hu et al. 2010). These pathological changes in neurons in the hippocampal region correspond well with clinical findings of glucocorticoids modulated acquisition, consolidation, and retrieval of spatial memory in rats and humans (Rashidy-Pour et al. 2004), and with negative effects on declarative and working memory (Brown 2009). Dexamethasone, a highly potent synthetic glucocorticoid (Kawata 1995; Yahaya et al. 2018), induces neuronal apoptosis in the hippocampus (Almeida et al. 2000; Reagan \& McEwen 1997).

Neurons in the hippocampus damaged by high levels of glucocorticoids or dexamethasone are mostly nonpyramidal, GABAergic interneurons (Filipović et al. 2013; $\mathrm{Hu}$ et al. 2010). Despite targeted by the hormones, these neurons also contain a substance called parvalbumin (PV), a $\mathrm{Ca}^{++}$-binding protein that could prevent the damage by sequestering excessive $\mathrm{Ca}^{++}$results from the hormonal assault (Bergmann et al. 1991; Celio 1986; Plogmann \& Celio 1993; McPhalen et al. 1994; Sloviter 1989). Therefore, these interneurons possess naturally protective mechanisms, which might yield to the damage caused by an excessive level of glucocorticoids in their surroundings. The damage of these interneurons could also lead to a compromise in their inhibitory actions on other types of neurons in the hippocampus.

The function of these PV-containing, GABAergic interneurons in the hippocampus is to modulate shortterm synaptic plasticity (Caillard et al. 2000) and, thus, are essential for spatial working memory (Murray et al. 2011; Ognjanovski et al. 2017). This may partially explain why alteration in the number of these interneurons in Alzheimer's disease and age-related cognitive defects affects learning and memory process (Cowan et al. 1990; Verret et al. 2012).

The watercress, Nasturtium officinale R.Br. (locally called Phak-nam Be-tong), a leafy perennial herb found in southern Thailand (Betong district, Yala province), has been listed among Chinese traditional herbs with antioxidant activity that enhances physical stamina during exercise-induced stress condition (Fogarty et al. 2013; Hun Lee et al. 2013). Its active components include ascorbic acid, beta-carotene and other phenolic compounds (Yazdanparast et al. 2008). With its antioxidant activity, the plant has been proposed for its potential to prevent chronic diseases such as cancer (Gill et al. 2007) and heart diseases (Yazdanparast et al. 2008). Thus far, no scientific report of neuroprotective action of this plant extracts has appeared in literature; the objective of this study was therefore, to investigate if the watercress, $N$. officinale, has any neuroprotective effect in dexamethasone-induced neurodegeneration in mouse model, using learning ability of the animals and the density of PV-containing, GABAergic interneurons in the hippocampus of the mouse brain as indicators.

\section{MATERIALS AND METHODS}

\section{PLANT PREPARATION}

The watercress, $N$. officinale, were originally collected from Betong district, Yala province during March-April of 2012 and kept at the herbarium library (Herbarium no. SKP210141501), Department of Pharmacognosy, Faculty of Pharmaceutical Sciences, Prince of Songkla University. Twenty $\mathrm{kg}$ of the aerial part of the plant were dried in an oven at $50^{\circ} \mathrm{C}$ for three days to obtain $500 \mathrm{~g}$ dry material, which was milled and extracted with ethanol by percolation method (Shahrokhi et al. 2009). Rotary evaporator under reduced pressure was used to remove ethanol from the crude extract, which was approximately $7 \%$ yield of the total dry material. The watercress extract (WCE) was kept under airtight and light-protected conditions at $-20^{\circ} \mathrm{C}$ until use.

\section{RADICAL SCAVENGING ASSAY OF 2, 2-DIPHENYL-1- PICRYLHYDRAZYL (DPPH)}

DPPH assay was carried out by modifying the method of Jothy et al. (2011), using butylated hydroxyl toluene (BHT), a known antioxidant agent, as the standard control. Briefly, $2 \mathrm{mg}$ of the WCE was dissolved in $10 \mathrm{~mL}$ of absolute ethanol to make a stock solution, from which $2 \mathrm{~mL}$ were mixed with $2 \mathrm{~mL}$ of DPPH solution and incubated for $20 \mathrm{~min}$. The reaction mixture was read by a spectrophotometer at 520 nm OD against blank (a mixture of $2 \mathrm{~mL}$ each of watercress extract and absolute ethanol). The control sample was composed of a mixture of $2 \mathrm{~mL}$ each of absolute ethanol and DPPH. The antioxidant activity was calculated as: \% inhibition $=\left(\mathrm{OD}_{\text {control }}-\mathrm{OD}_{\text {sample }}\right) \times 100 / \mathrm{OD}_{\text {control }}$.

\section{ANIMAL PREPARATION}

Male Swiss albino mice (35-40 g) were obtained from the National Animal Center, Salaya, Nakhon Pathom, Thailand. The animals were housed in controlled temperature at $25 \pm 2{ }^{\circ} \mathrm{C}$ and a light-dark cycle of $12 \mathrm{~h}$ each with food and water ad libitum. They were randomly assigned to different interventions for 6 groups, 10 mice each. All protocols used for the animals were approved by the Animal Ethics Committee of Prince of Songkla University (MOE0521.11/1075). The animals were divided into 6 groups: Double distilled water (DW) and normal saline solution (NSS) (DW+NSS), DW and dexamethasone-treated for 21 days (DW+DEX), $80 \mathrm{mg} / \mathrm{kg}$ of watercress extract (WCE) and NSS (80WCE+NSS), and WCE-treated at variable doses $20 \mathrm{mg} / \mathrm{kg}$ (20WCE+DEX), $40 \mathrm{mg} / \mathrm{kg}$ (40WCE+DEX), and $80 \mathrm{mg} / \mathrm{kg}$ (80WCE+DEX). The animals received WCE per oral daily for 14 days, followed by intraperitoneal injection of $60 \mathrm{mg}$ dexamethasone per $\mathrm{kg}$ body weight (BW) of the animal daily for 21 days, meanwhile the animals were continuously supplied with WCE. Control animals received distilled water (DW) instead of WCE and normal saline solution (NSS) instead of dexamethasone. The dose and duration of dexamethasone treatment were 
modified from the work of Tongjaroenbuangam et al. (2011). Dexamethasone was prepared by diluting Dexon ${ }^{\circledR}$ (General Drugs House co., Ltd.) with normal saline solution $(0.9 \% \mathrm{NaCl})$ to the final concentration $(60 \mathrm{mg} / \mathrm{mL}$ BW). The dose and duration of WCE treatment were adapted from the results of Uabundit et al. (2010).

\section{COGNITION, LEARNING AND MEMORY TEST}

At the end of the experimental treatment (Day 35), cognition, learning, and memory test was performed using a modified Morris Water Maze (MWM) apparatus from the work of D'Hooge and Deyn (2001). The test, a swimming-based model in which the animal learns to escape to a hidden platform, is widely used to investigate spatial learning and memory capacity in rodents (Morris 1984). The training sessions were composed of three trials per day and continued for three consecutive days. For the training period, the water level in MWM was decreased beneath the platform for $1 \mathrm{~cm}$. The platform was located in a fixed position until finishing the test. In the training session, animals were individually placed into the maze by tail-end first and allowed to swim freely in the tank for 60 s. If the animals could find the platform within the given time, they would be allowed to stay on the platform for 15 $\mathrm{s}$ before being removed from the maze. The animals that failed to achieve the task were guided by the researcher to the platform. In the test session, the level of water was raised to $1 \mathrm{~cm}$ above the platform. The water surface was blinded by non-toxic milk powder. The time that animals spent to find the platform was recorded as escape latency time (ELT).

\section{BRAIN SPECIMEN PREPARATION}

Upon completing the water maze experiment, the animals were deeply anesthetized by intraperitoneal injection of Anesthal $^{\circledR}$ (Jagsonpal Pharma) at $60 \mathrm{mg} / \mathrm{kg}$ mouse BW and perfused transcardially with $4 \%$ paraformaldehyde in pH7.4 phosphate buffer solution (PBS). The brains were removed, post-fixed with $4 \%$ paraformaldehyde in PBS for $72 \mathrm{~h}$ at room temperature and cryoprotected by equilibration with $30 \%$ sucrose in PBS until being saturated. Serial frozen sections with $40 \mu \mathrm{m}$-thickness were prepared coronally using a cryostat (LEICA CM 1850). Every fifth section of the brain was randomly selected and coded so that all subsequent analyses were carried out blind.

\section{IMMUNOHISTOCHEMISTRY}

Immunohistochemical method to detect PV in the mouse brains was carried out, using a protocol modified from the works of Udomuksorn et al. (2011) and Vongvatcharanon et al. (2010). Briefly, the sections were incubated in $10 \%$ normal horse serum (Vector Lab, Burlingame, CA) with 0.2\% Triton-X 100 (J.T. Baker Inc, Phillipsburg, NJ) for $30 \mathrm{~min}$. The sections were then incubated in anti-PV mouse monoclonal antibody at a dilution 1:200 (SigmaAldrich Chemical Company, St. Louis, MO) overnight at $4^{\circ} \mathrm{C}$. After washing with $0.1 \mathrm{M}$ PBS, the sections were incubated in Texas red-conjugated anti-mouse $\operatorname{IgG}(1: 200$ dilution, Vector Lab, Burlingame, CA) for $1 \mathrm{~h}$. Finally, the sections were washed with $0.1 \mathrm{M}$ PBS and mounted with Vectashield (Vector Lab, Burlingame, CA), cover-slipped and sealed with nail polish. Controls were performed by either omitting the first or secondary antibody. None of these controls showed any labeling.

\section{QUANTIFICATION OF PV-IMMUNOREACTIVE NEURONS}

Four regions of the hippocampus were examined: cornu ammonis (CA) 1, CA2, CA3, and dentate gyrus. Ten sections from individual animals were analyzed for immunolabelling of PV-immunoreactive neurons (PVir neurons). Images taken from selected sections were captured by a digital camera (DP50, Olympus, Japan). The number of PV-ir neurons in each micrograph was counted and the area of each examined section was measured using image analysis software. The results were expressed as numbers of PV-ir neurons per $\mathrm{mm}^{2}$.

\section{STATISTICAL ANALYSIS}

Data were expressed as mean \pm SD. Comparing the differences of means among groups were carried out by one-way ANOVA followed by Tukey-HSD. The significant difference was considered at $\mathrm{p}<0.05$.

\section{RESULTS AND DISCUSSION}

\section{DPPH RADICAL SCAVENGING ASSAY OF WCE}

The general appearance of WCE was dark-green color with viscous property. In DPPH assay, it showed $58.3 \%$ inhibition, while BHT, a standard antioxidant agent, showed $54.9 \%$ inhibition. In addition, IC50 of WCE and BHT were 6.7 and $5.1 \mathrm{mg} / \mathrm{mL}$, respectively.

\section{SURVIVAL AND BODY WEIGHTS OF THE ANIMALS}

The animals of DW + NSS and 80wCE + NSS groups, which did not receive dexamethasone, had $100 \%$ survival (Figure 1(a)); while the animals in other groups that received dexamethasone had variable levels of survival, the animals of DW + DEX group that received only dexamethasone survived at $50 \%$. The animals of $20 \mathrm{WCE}+$ DEX, 40WCE + DEX, and 80WCE + DEX groups, that received dexamethasone and WCE at 20,40, and $80 \mathrm{mg} / \mathrm{kg}$ BW daily survived at $75 \%, 70 \%$, and $80 \%$, respectively. The BW of the animals in all groups before dexamethasone treatment, at day 14 of the experiment, did not differ statistically (Figure 1(b)). However, at the end of the experiment, at day 35 , the animals in DW + DEXA, 40WCE + DEX, and $80 \mathrm{WCE}+$ DEX groups had significantly $(\mathrm{p}<0.05)$ lower $\mathrm{BW}$, compared to that of DW + NSS, 80WCE + NSS, and 20WCE + DEX groups (Figure 1(b)). The findings that dexamethasone treatment reduced survival and body weight of the experimental mice correspond to previous 
reports that glucocorticoids inhibit somatic growth in rats by decreasing growth hormone secretion and increasing protein catabolism (Tulipano et al. 2007). Induced by the metabolic changes, dexamethasone also inhibits appetite resulting from an indirect action on the hypothalamus (Liu et al. 2011). In this study, oral administration of WCE prior to and during the dexamethasone treatment reduced the effects of dexamethasone on the survival but not the body weight of the animals. As mentioned, dexamethasone has effects on eating behavior and the release of growth hormone of the animals, so the findings suggest that WCE could not counteract these effects.

\section{MORRIS WATER MAZE TEST}

The level of learning ability and spatial memory performance, represented by ELT, showed a statistically significant difference among groups (Figure 1(c)). The control animals in DW + NSS and 80WCE + NSS groups had the lowest duration of ELT, which was presumably the basic score of ELT of normal mice. The mice in DW + DEX group which received only dexamethasone, had significantly $(\mathrm{p}<0.05)$ higher ELT than that of DW + NSS and 80WCE + NSS groups, suggesting the impairment of their memory function. This impairment might partially improve by WCE, as the ELT was shortened in 20WCE + DEX, $40 \mathrm{WCE}+\mathrm{DEX}$, and 80WCE + DEX groups, which received dexamethasone and variable levels of WCE. However, the effect of WCE was not dose-related, as only 40wCE + DEX group, which received $40 \mathrm{mg}$ WCE showed significantly lower $(\mathrm{p}<0.05)$ ELT than that of DW + DEX_group. The focus of this study, however, was on the recognition and memory function of the animals. The mice treated with dexamethasone DW + DEX group had prolonged ELT, suggesting that the dexamethasone treatment affected the learning and memory of the animals. Similar findings were previously reported by other investigators (Almeida et al. 2000; Hu et al. 2010; Reagan \& McEwen 1997; Woolley et al. 1990; Yun et al. 2003).

Animals treated with WCE showed a reduced level of ELT but a significant reduction was found only in the animals receiving $40 \mathrm{mg} / \mathrm{kg} \mathrm{BW}$. Although the results suggested that learning ability and spatial memory performance impaired by dexamethasone treatment could be partially improved by WCE, the effect of WCE was not dose-related. The ELT test is a behavioral test and therefore the results may not be accurately graded when doses of WCE were compared.

\section{DENSITY OF PV-IR NEURONS IN THE HIPPOCAMPUS}

All four regions of the hippocampus: CA1, CA2, CA3, and DG showed that PV-ir neurons, with more abundant of the neurons in CA1 and CA2 than those in CA3 and DG (Figures 2 and 4). Following dexamethasone treatment (DW + DEX), PV-ir neurons were reduced in density, visually (Figure 3) and quantitatively (Figure 4); the reduction was clearly observed in CA1 and CA2 regions, but not in CA3 and DG regions. In CA1 region, the animals that received only
WCE at $80 \mathrm{mg} / \mathrm{kg}$ BW (80WCE + NSS) showed a significant $(\mathrm{p}<0.05)$ increase in the density of the neurons, compared to that of the control animals that received only distilled water and normal saline solution (DW + NSS). The animals that were supplemented with WCE while treated with dexamethasone (20WCE + DEX, 40WCE + DEX and 80WCE + DEX groups) decreased in the density, but only 80wCE + DEX group (receiving $80 \mathrm{mg} / \mathrm{kg} \mathrm{BW}$ ) was significantly $(\mathrm{p}<0.05)$ lower than that of DW + NSS group. The densities of these three groups of animals did not differ significantly from each other but were significantly $(\mathrm{p}<0.01)$ higher than the density in DW + DEX group, suggesting a partial improvement of the neuronal numbers suppressed by dexamethasone treatment. This improvement may not be dose-related as the density was not increased by increasing the levels of WCE supplement. On the contrary, with higher levels of supplement, the density tended to decrease, and the $80 \mathrm{WCE}+$ DEX group (with $80 \mathrm{mg} / \mathrm{kg} \mathrm{BW}$ supplement) showed significant $(\mathrm{p}<0.05)$ difference from that of DW + NSS group. In CA2, the density of the PV-ir neurons seemed to follow that of CA1. Exceptional was that no significant difference in density was found between DW + NSS and $80 \mathrm{WCE}+$ DEX groups. The density of PV-ir neurons in the CA3 and DG was much lower than that of the CA1 and CA2, and no statistical difference was detected among the groups within the same brain region.

Additionally, to up-to-date knowledge, our study suggests that dexamethasone treatment reduces the density of PV-ir neurons in the CA1 and the CA2 regions of the hippocampus. Activity in the CA1 is important for consolidating episodic memories, with PV-expressing interneurons function as coordinating hippocampal network dynamically involves memory consolidation (Ognjanovski et al.2017). Therefore, the decreased density of PV-neurons in the CA1 and CA2 as consequence of dexamethasone treatment could be one of the mechanisms leading to the decrease of learning ability and spatial memory. This reduction likely signifies the death of neurons containing $\mathrm{PV}$, which may result from an alteration of calcium homeostasis in the neuronal cytoplasm (McPhalen et al. 1994; Plogmann \& Celio 1993).

The finding that all groups of the mice supplemented with WCE had a significantly higher number of PV-ir neurons in the CA1 and CA2 than those treated with dexamethasone alone, but still lower than those of the control mice, suggests that WCE could partially protect PV-ir neurons from dexamethasone. Similar to the ELT results, the protective effect of WCE on the neurons was the same at all levels of WCE tested. The dose of dexamethasone treatment might be too high for WCE to counteract, and therefore the level of protection cannot be graded by different doses of the extract. Nevertheless, a certain degree of protection was detected.

The density of the PV-ir neurons in the mice given only $80 \mathrm{mg} / \mathrm{kg}$ BW of WCE (80WCE + NSS group) was significantly higher than that of the control mice that received only vehicles. This unexpected result suggests that 


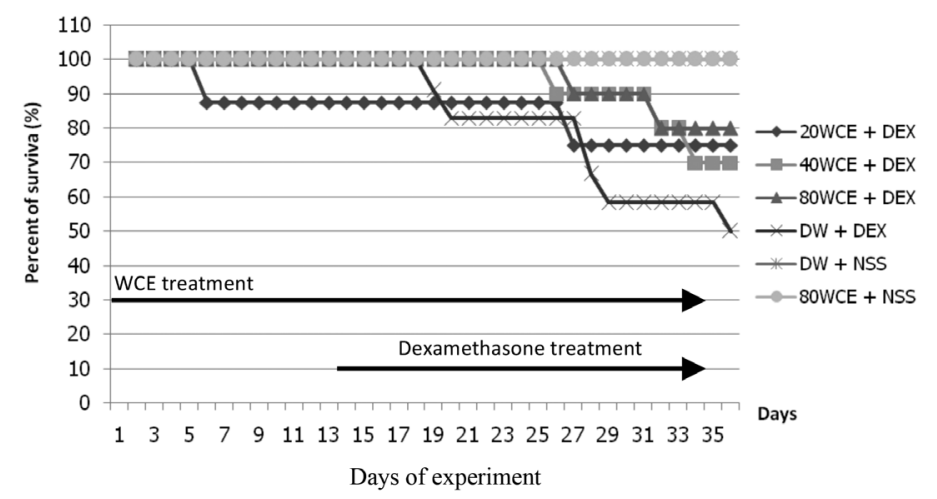

(a) \% Survival

Before DEX (day 14)

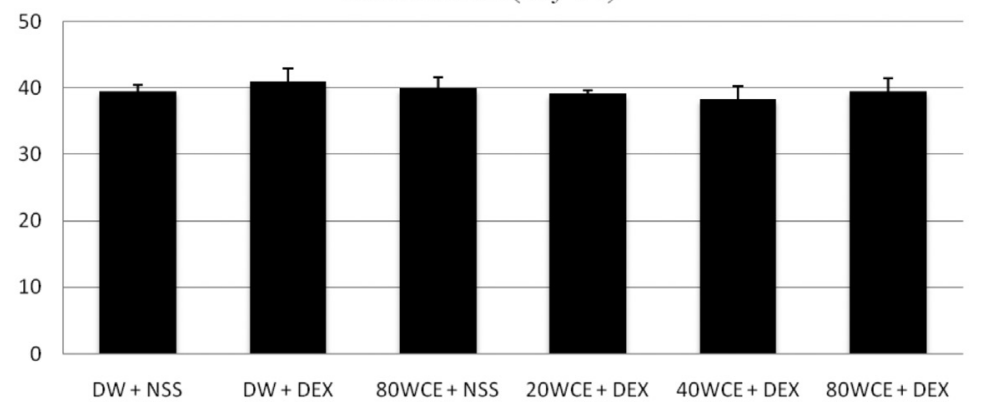

After DEX (day 35)

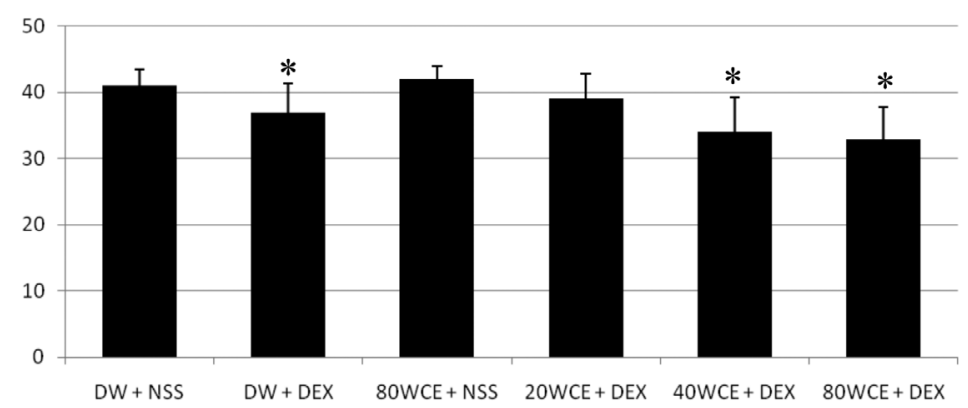

(b) Body Weight (g)

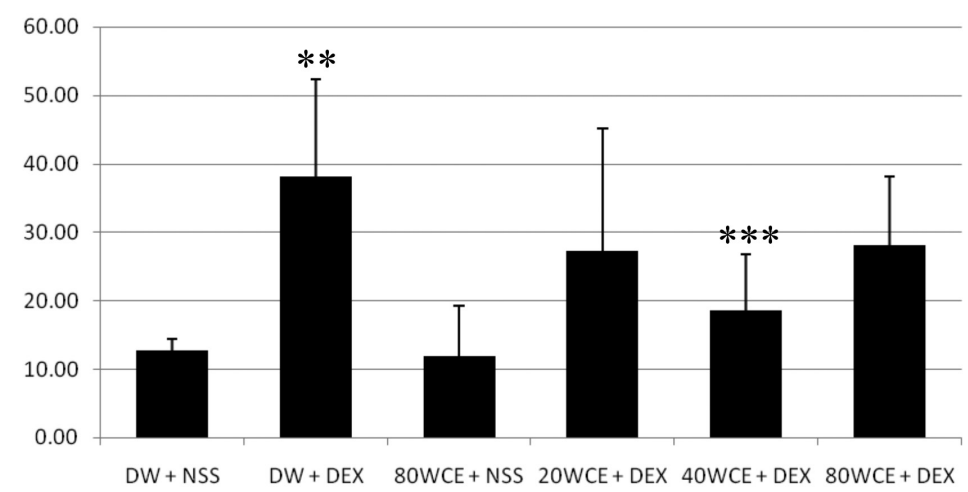

(c) ELT (sec)

* Significantly different as compared to the DW + NSS, 80WCE + NSS and $20 \mathrm{WCE}+$ DEX groups $(\mathrm{p}<0.05)$

** Significantly different as compared to the DW + NSS and 80WCE + NSS groups $(\mathrm{p}<0.05)$

*** Significantly different as compared to the DW + DEX group $(\mathrm{p}<0.05) \mathrm{DW}$, distilled water; ELT, escape latency time; NSS, normal saline solution; WCE, watercress extract; DEX, dexamethasone

FIGURE 1. Survival (a), body weight (b) and escape latency time (c) of mice treated with dexamethasone, with and without watercress extract administration $(n=10)$ 

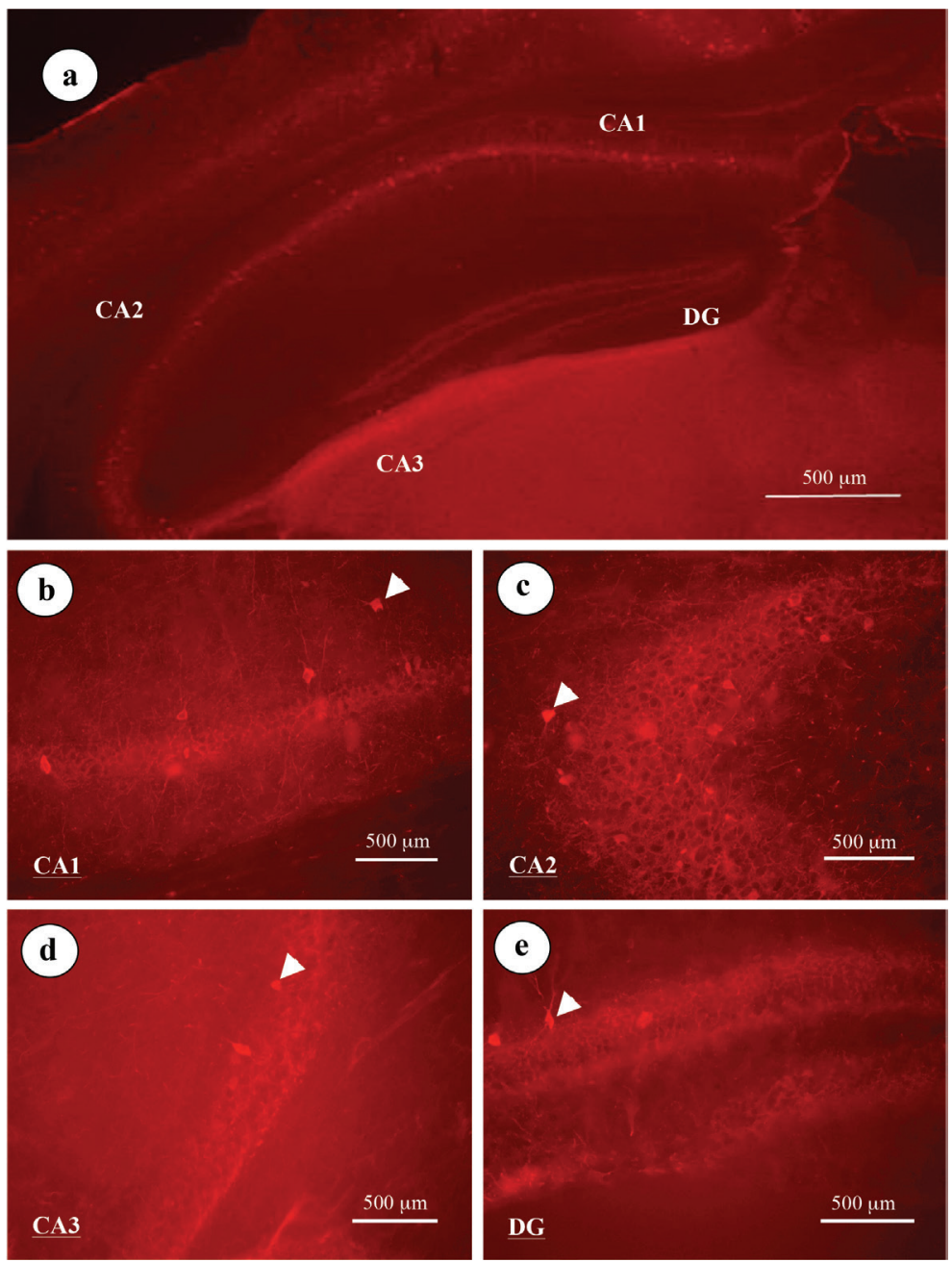

FIGURE 2. Photomicrographed immunohistochemical sections of normal mice with parvalbumin (PV)specific antibody, in the hippocampus (a), and its individual regions (b-e). Arrows point to examples of PV-immunoreactive neurons in each region. CA, cornu ammonis; DG, dentate gyrus

WCE could increase the density of neurons, although this was not accompanied by the lower ELT value. How WCE causes the increase in the neuronal density is an interesting topic for further research.

Mechanism(s) by which WCE protect(s) the brain from dexamethasone-induced learning and memory impairment remained unknown, although this study showed its antioxidant activity as shown by the DPPH radical scavenging assay. Major components in WCE include ascorbic acid, $\beta$-carotene, and other phenolic compound (Gill et al .2007); most of these compounds are natural anti-oxidant and has potential to recycle $\alpha$-tocopherol in the lipid bilayer. Besides the anti-oxidants, WCE serves as a rich source of glucosinolates (Jeon et al. 2017; Voutsina et al. 2016; Zeb 2015). Among several glucosinolates, gluconasturtiin (2-phenethyl glucosinolate) was the substance that is worth to explore further. The substance, hydrolyzed by myrosinase to a 2-phennethyl isothiocyanate, suppresses carcinogen activation through the inhibition of phase I enzymes (such as the cytochrome P450 family) and induction of phase II enzymes (such as the glutathione transferase family) and thus prevent DNA damage (Johnson 2002). How these mechanisms are related to the protective effect of WCE against dexamethasone assault of the PV-ir neurons in the hippocampus is not yet identified but it is unlikely that the protection could be explained only by the antioxidant effect of WCE.

\section{CONCLUSION}

Mice pre-treated with WCE were partially protected against dexamethasone-induced neurotoxicity. Watercress might have potential for the prevention of stress-induced physical and cognitive decline. Further studies to identify the active compounds and their mechanism of actions are on-going.

\section{ACKNOWLEDGEMENTS}

The authors wish to thank the Department of Pharmacology, Physiology, and Anatomy, Faculty of Science and the Department of Pharmaceutical Botany and Pharmacognosy, Faculty of Pharmaceutical Sciences, Prince of Songkla University for providing instruments and laboratory 

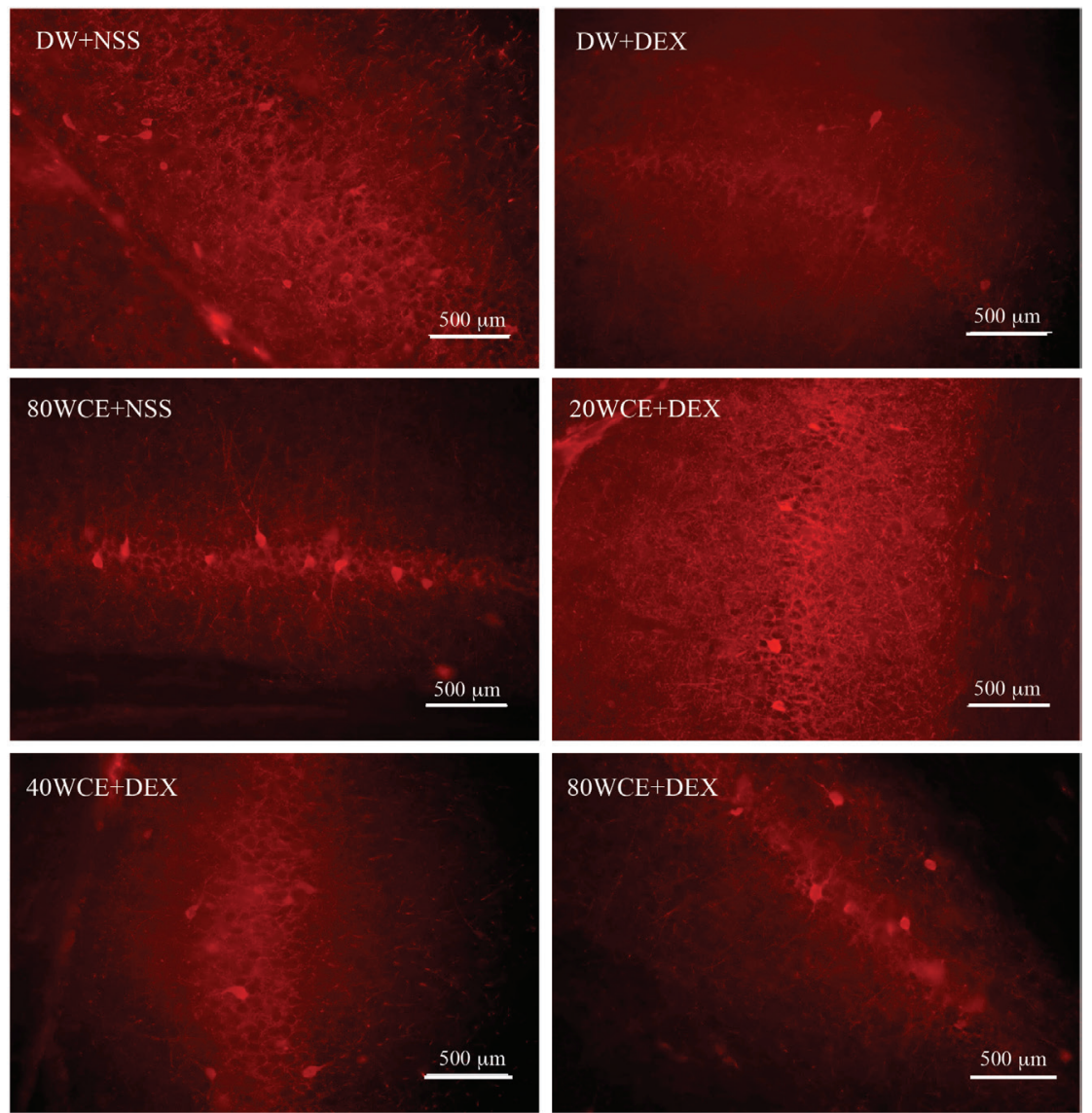

FIGURE 3. Photomicrographed immunohistochemical sections of mouse brain showing PV-immunoreactive neurons in the CA1 region of the hippocampus. Each section was CA1 from different groups of animals $(n=6)$

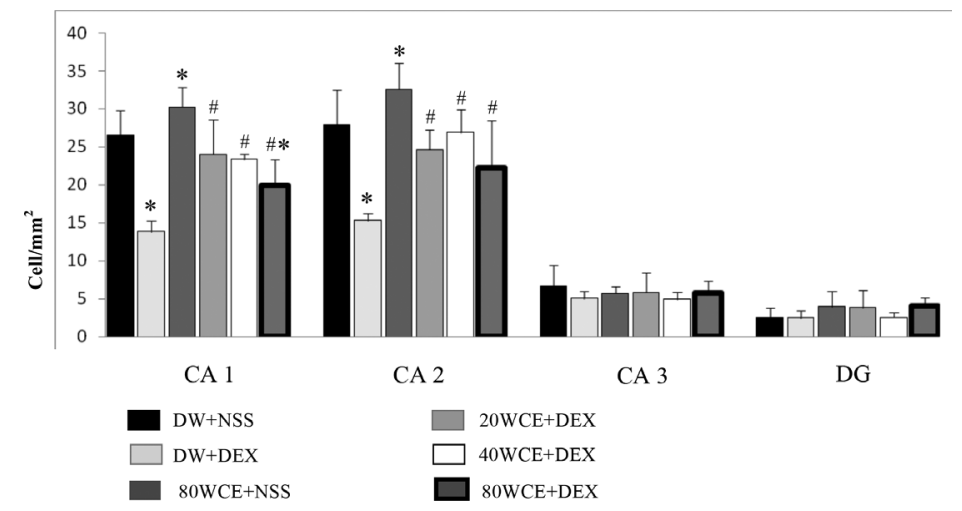
* Significantly different as compared to the DW + NSS group $(\mathrm{p}<0.05)$
\# Significantly different as compared to the DW + DEX group $(\mathrm{p}<0.01)$
CA, cornu ammonis; DG, dentate gyrus; DW, distilled water; NSS, normal saline solution; WCE, water
cress extract; DEX, dexamethasone $(\mathrm{n}=6)$

FIGURE 4. Density of PV-immunoreactive neurons in different regions of hippocampus of different groups of mice

facilities support. We also would like to thank Professor Boonsirm Withyachumnarnkul for editing and providing valuable suggestions for the manuscript and Mrs. Anna Chatthong for the assistance with the English proofreading manuscript. This study was financially supported by Graduate School and Research Assistant Scholarship, Faculty of Science, Prince of Songkla University.
REFERENCES

Almeida, O.F.X., Conde, G.L., Crochemore, C., Demeneix, B.A., Fischer, D., Hassan, A.H.S., Meyer, M., Holsboer, F. \& Michaelidis, T.M. 2000. Subtle shifts in the ratio between proand antiapoptotic molecules after activation of corticosteroid receptors decide neuronal fate. Federation of American Societies for Experimental Biology Journal 14: 779-790. 
Ballard, C., Gauthier, S., Corbett, A., Brayne, C., Aarsland, D. \& Jones, E. 2011. Alzheimer's disease. Lancet 377: 1019-1031.

Ball, M.J. 1978. Topographic distribution of neurofibrillary tangles and granulovacuolar degeneration in hippocampal cortex of aging and demented patients. A quantitative study. Acta Neuropathologica 42(2): 73-80.

Behl, C. 1998. Effects of glucocorticoids on oxidative stress-induced hippocampal cell death: Implications for the pathogenesis of Alzheimer's disease. Experimental Gerontology 33(7-8): 689-696.

Bergmann, I., Nitsch, R. \& Frotscher, M. 1991. Area-specific morphological and neurochemical maturation of nonpyramidal neurons in the rat hippocampus as revealed by parvalbumin immunocytochemistry. Anatomy and Embryology 184: 403-409.

Brown, E.S. 2009. Effects of glucocorticoids on mood, memory, and the hippocampus treatment and preventive therapy. Annals of the New York Academy of Sciences 1179: 41-55.

Caillard, O., Moreno, H., Schwaller, B., Llano, I., Celio, M.R. \& Marty, A. 2000. Role of the calcium-binding protein parvalbumin in short-term synaptic plasticity. Proceedings of the National Academy of Sciences 97(24): 13372-13377.

Celio, M.R. 1986. Parvalbumin in most gamma-aminobutyric acid-containing neurons of the rat cerebral cortex. Science 231(4741): 995-997.

Chrousos, G.P. \& Kino, T. 2009. Glucocorticoid signaling in the cell expanding clinical implications to complex human. behavioral and somatic disorders. Annals of the New York Academy of Sciences 1179: 153-166.

Coleman, P.D.\& Flood, D.G. 1987. Neuron numbers and dendritic extent in normal aging and Alzheimer's disease. Neurobiology of Aging 8(6): 521-545.

Cowan, R.L., Wilson, C.J., Emson, P.C. \& Heizmann, C.W. 1990. Parvalbumin-containing GABAergic interneurons in the rat neostriatum. Journal of Comparative Neurology 302(2): 197-205.

D'Hooge, R. \& De Deyn, P.P. 2001. Applications of the Morris water maze in the study of learning and memory. Brain Research Reviews 36(1): 60-90.

Filipović, D., Zlatković, J., Gass, P. \& Inta, D. 2013.The differential effects of acute vs. chronic stress and their combination on hippocampal parvalbumin and inducible heat shock protein 70 expression. Neuroscience 236: 47-54.

Fogarty, M.C., Hughes, C.M., Burke, G., Brown, J.C. \& Davison, G.W. 2013. Acute and chronic watercress supplementation attenuates exercise-induced peripheral mononuclear cell DNA damage and lipid peroxidation. British Journal of Nutrition 109(02): 293-301.

Gill, C.I., Haldar, S., Boyd, L.A., Bennett, R., Whiteford, J., Butler, M., Pearson, J.R., Bradbury, I. \& Rowland, IR. 2007. Watercress supplementation in diet reduces lymphocyte DNA damage and alters blood antioxidant status in healthy adults. American Journal of Clinical Nutrition 85(2): 504510 .

Hu, W., Zhang, M., Czéh, B., Flügge, G. \& Zhang, W. 2010. Stress impairs GABAergic network function in the hippocampus by activating nongenomic glucocorticoid receptors and affecting the integrity of the parvalbumin-expressing neuronal network. Neuropsychopharmacology 35: 1693-1707.

Hun Lee, J., Shu, L., Fuentes, F., Su, Z.Y. \& Tony Kong, A.N. 2013. Cancer chemoprevention by traditional chinese herbal medicine and dietary phytochemicals: Targeting Nrf2-mediated oxidative stress/anti-inflammatory responses, epigenetics, and cancer stem cells. Journal of Traditional and Complementary Medicine 3(1): 69-79.

Jeon, J., Bong, S.J., Park, J.S., Park, Y.K., Arasu, M.V., Al-Dhabi, N.A.\& Park, S.U. 2017. De novo transcriptome analysis and glucosinolate profiling in watercress (Nasturtium officinale R. Br.). BMC Genomics 18(1): 401.

Johnson, I.T. 2002. Glucosinolates in the human diet. Bioavailability and implications for Health. Phytochemistry Reviews 1: 183-188.

Jothy, S.L., Zuraini, Z. \& Sasidharan, S. 2011. Phytochemicals screening, DPPH free radical scavenging and xanthine oxidase inhibitiory activities of Cassia fistula seeds extract. Journal of Medicinal Plants Research 5(10): 1941-1947.

Kawata, M. 1995. Roles of steroid hormones and their receptors in structural organization in the nervous system. Neuroscience Research 24(1): 1-46.

Liu, X.Y., Shi, J.H., Du, W.H., Fan, Y.P., Hu, X.L., Zhang, C.C., Xu, H.B., Miao, Y.J., Zhou, H.Y., Xiang, P. \& Chen, F.L. 2011. Glucocorticoids decrease body weight and food intake and inhibit appetite regulatory peptide expression in the hypothalamus of rats. Experimental and Therapeutic Medicine 2(5): 977-984.

McPhalen, C.A., Sielecki, A.R., Santarsiero, B.D. \& James, M.N. 1994. Refined crystal structure of rat parvalbumin, a mammalian alpha-lineage parvalbumin, at 2.0A resolution. Journal of Molecular Biology 235(2): 718-732.

Morris, R. 1984. Developments of a water-maze procedure for studying spatial learning in the rat. Journal of Neuroscience Methods 11(1): 47-60.

Murray, A.J., Sauer, J.F., Riedel, G., McClure, C., Ansel, L., Cheyne, L., Bartos, M., Wisden, W. \& Wulff, P. 2011. Parvalbumin-positive CA1 interneurons are required for spatial working but not for reference memory. Nature Neuroscience 14(3): 297-299.

$\mathrm{Ng}$, T.P. 2016. Cognitive health of older persons in longitudinal ageing cohort studies. Sains Malaysiana 45(9): 1351-1355.

Ognjanovski, N., Schaeffer, S., Wu, J., Mofakham, S., Maruyama, D., Zochowski, M. \& Aton, S.J. 2017. Parvalbuminexpressing interneurons coordinate hippocampal network dynamics required for memory consolidation. Nature Communications 8: 15039.

Plogmann, D. \& Celio, M.R. 1993. Intracellular concentration of parvalbumin in nerve cells. Brain Research 600(2): 273-279.

Rashidy-Pour, A., Sadeghi, H., Taherain, A.A., Vafaei, A.A. \& Fathollahi, Y. 2004. The effects of acute restraint stress and dexamethasone on retrieval of long-term memory in rats: An interaction with opiate system. Behavioural Brain Research 154(1): 193-198

Reagan, L.P. \& McEwen, B.S. 1997. Controversies surrounding glucocorticoid-mediated cell death in the hippocampus. Journal of Chemical Neuroanatomy 13(3): 149-167.

Shahrokhi, N., Hadad, M.K., Keshavarzi,Z. \& Shabani, M. 2009. Effects of aqueous extract of water cress on glucose and lipis plasma in streptozotocin induced diabetic rats. Pakistan Journal of Physiology 5(2): 6-10.

Sloviter, R.S. 1989. Calcium-binding protein $\left(\right.$ Calbindin- $\left.\mathrm{D}_{28 \mathrm{k}}\right)$ and parvalbumin immunocytochemistry: Localization in the rat hippocampus with specific reference to the selective vulnerability of hippocampal neurons to seizure activity. Journal of Comparative Neurology 280(2): 183-196.

Tongjaroenbuangam, W., Ruksee, N., Chantiratikul, P., Pakdeenarong, N., Kongbuntad, W. \& Govitrapong, P. 2011. Neuroprotective effects of quercetin, rutin and okra 
(Abelmoschus esculentus Linn.) in dexamethasone-treated mice. Neurochemistry International 59(5): 677-685.

Tulipano, G., Taylor, J.E., Halem, H.A., Datta, R., Dong, J.Z., Culler, M.D., Bianchi, I., Cocchi, D. \& Giustina, A. 2007. Glucocorticoid inhibition of growth in rats: Partial reversal with the full-length ghrelin analog BIM-28125. Pituitary 10(3): 267-274.

Uabundit, N., Wattanathorn, J., Mucimapura, S. \& Ingkaninan, K. 2010. Cognitive enhancement and neuroprotective effects of Bacopa monnieri in Alzheimer's disease model. Journal of Ethnopharmacology 127(1): 26-31.

Udomuksorn, W., Mukem, S., Kumarnsit, E., Vongvatcharanon, S. \& Vongvatcharanon, U. 2011. Effect of alcohol administration during adulthood on parvalbumin and glial fibrillary acidic protein immunoreactivity in rat cerebral cortex. Acta Histochemica 113(3): 283-289.

Verret, L., Mann, E.O., Hang, G.B., Barth, A.M., Cobos, I., Ho, K., Devidze, N., Masliah, E., Kreitzer, A.C., Mody, I., Mucke, L. \& Palop, J.J. 2012. Inhibitory interneuron deficit links altered network activity and cognitive dysfunction in Alzheimer model. Cell 149(3): 708-721.

Vongvatcharanon, U., Mukem, S., Udomuksorn, W., Kumarsit, E. \& Vongvatcharanon, S. 2010. Alcohol administration during adulthood induces alterations of parvalbumin and glial fibrillary acidic protein immunoreactivity in rat hippocampus and cingulate cortex. Acta Histochemica 112(4): 392-401.

Voutsina, N., Payne, A.C., Hancock, R.D., Clarkson, G.J., Rothwell, S.D., Chapman, M.A. \& Taylor, G. 2016. Characterization of the watercress (Nasturtium officinale $\mathrm{R}$. Br.; Brassicaceae) transcriptome using RNASeq and identification of candidate genes for important phytonutrient traits linked to human health. BMC Genomics 17: 378.

Woolley, C.S., Gould, E. \& McEwen, B.S. 1990. Exposure to excess glucocorticoids alters dendritic morphology of adult hippocampal pyramidal neurons. Brain Research 531(1-2): 225-231

Yahaya, M.F., Zainodin, A., Pupathy, R., Min, E.O.H., Bakar, N.H.A., Zamri, N.A., Ismail, H. \& Mohd Ramli, E.S. 2018. The effect of palm tocotrienol on surface osteoblast and osteoclast in excess glucocorticoid osteoporotic rat model. Sains Malaysiana 47(11): 2731-2739.

Yazdanparast, R., Bahramikia, S. \& Ardestan, A. 2008. Nasturtium officinale reduces oxidative stress and enhances antioxidant capacity in hypercholesterolaemic rats. ChemicoBiological Interactions 172: 176-184.
Yun, S.J., Lee, D.J., Kim, M.O., Jung, B., Kim, S.O., Sohn, N.W. \& Lee, E.H. 2003. Reduction but not cleavage of poly (ADPribose) polymerase during stress-mediated cell death in the rat hippocampus. NeuroReport 14(7): 935-939.

Warit Ruanglertboon \& Wandee Udomuksorn*

Department of Pharmacology

Faculty of Science

Prince of Songkla University

Hatyai, Songkhla 90110

Thailand

Ekkasit Kumarnsit

Department of Physiology

Faculty of Science

Prince of Songkla University

Hatyai, Songkhla 90110

Thailand

Sukanya Dej-Adisai

Department of Pharmacognosy and Pharmaceutical Botany

Faculty of Pharmaceutical Sciences

Prince of Songkla University

Hatyai, Songkhla 90110

Thailand

Uraporn Vongvatcharanon

Department of Anatomy

Faculty of Science

Prince of Songkla University

Hatyai, Songkhla 90110

Thailand

*Corresponding author; email: wandee.u@psu.ac.th

Received: 14 February 2019

Accepted: 20 August 2019 